\section{理化学研究所放射光科学 総合研究センターのご紹介}

国立研究開発法人理化学研究所. 放射光科学総合研究センター; センター長 石川哲也

\section{1. は じめに}

国立研究開発法人・理化学研究所は, 兵庫県佐用町にある 播磨事業所において大型放射光施設 SPring-8 と, X 線自由 電子レーザー施設 SACLA を所有し, 公益財団法人・高輝 度光科学研究センター (JASRI) と協力して，それらを先端基 盤施設として共用に供している. 同事業所に設置され，光源 から利用までの幅広い分野での放射光科学技術を推進してい るのが，放射光科学総合研究センターである. 本センターは 英語名を RIKEN SPring-8 Center とし，略称は RSCであ る.

センターのミッションは「(1) SPring-8 サイトにある独自 かつユニークな放射光関連施設を利用する研究を展開・推 進 ·先導し，(2) SPring-8の高度化を行うとともに次世代放 射光源に向けた研究開発を行う. その上で(3) SPring-8の認 知度を高めることに貢献し, 研究成果をさらに先端的な SPring-8 利用に反映させる.」と規定されており，光源開発 から利用研究をでを幅広く包含している.

\section{2. センター組織と活動}

上述のミッションを達成するため, センター組織は, (1)次 世代光源開発を行う先端光源開発研究部門，(2)放射光や X 線自由電子レーザーの新しい利用手法や計測装置開発研究を 行う利用技術開拓研究部門，(3)新たに開発された利用技術を 一般に利用しやすいシステムとして作りこみ, 理研ビームラ インを運用する利用システム開発研究部門, (4) X 線自由電 子レーザーに関して, 光源加速器から利用技術に至るまでの 一貫した開発研究を進めるXFEL 研究開発部門, (5)上記 4 部門のエンジニアリング課題を解決し, 加えて建築, ユーテ ィリティ，電気施設などの保守・高度化を行うエンジニアリ ング部門，(6)株式会社リガクと連携し，放射光利用手法を実 験室計測系に展開する方向性を探る, 理研 RSC-リガク連携 センター, (7)兵庫県立大学のリーディングプログラムに対応 するための, RSC-兵庫県立大リーディングプログラムセン ター，の 5 部門 2 サブセンターからなる.

当センターのセンター長は石川哲也, 副センター長は田中 均が務めている. 先端光源開発研究部門(後藤俊治部門長)に は, SPring-8, SACLA でのアンジュレータ開発を担当し, 次世代 X線レーザー開発研究を行う田中隆次主任研究員の
研究室があり, また SPring-8 の次期計画である SPring-8II や, $3 \mathrm{GeV}$ 高輝度放射光施設に向けた, マルチベントア クロマートラティスに基づく回折限界放射光源の研究開発を 行うグループがあり, 田中均がリーダーを務めている.

利用技術開拓研究部門 (石川哲也部門長)には, 超高分解能 $\mathrm{X}$ 線非弾性散乱計測で世界の第一線を走るアルフレッド. バロン主任研究員の研究室, 電子線回折手法でタンパク分子 構造解析を行う米倉功治主任研究員の研究室, 京大医学部の 岩田想教授を客員リーダーとし, SACLA でのタンパク構造 解析の手法開発に取り組むグループ, 東北大学多元研の高田 昌樹教授を客員リーダーとする可視化物質科学研究グループ がある。

利用システム開発研究部門 (山本雅貴部門長)には, SPring-8 の理研ビームラインの運用と高度化開発を行うビ 一ムライン基盤研究部(山本雅貴部長) と, 特にタンパク試料 調整や結晶化などの研究開発を行う, 国島直樹リーダーが率 いる生物試料基盤グループがある.

XFEL 研究開発部門(田中均部門長)では, SACLA の光源 加速器の運用と高度化を行う加速器研究開発グループを田中 均が統括し，データ処理を含むビームライン・エンドステー ションの運用と高度化を行うビームライン研究開発グループ を矢橋牧名が統括している，また X 線自由電子レーザーで の特異な $\mathrm{X}$ 線パルス構造に起因する放射線の諸問題に対処 するため，放射線評価グループが置かれ後藤俊治が統括して いる.

エンジニアリング部門(石川哲也部門長)は，現状では SACLA のユーザー実験に係る様々なエンジニアリング課題 の解決, $\mathrm{X}$ 線二次元検出器開発, データ収集・解析システ ムおよびソフトウェア開発を行うとともに，建屋建築，ユー ティリティ，電気関連設備などの施設関連業務を事務部門と 連携して進めている.

二つのサブセンターに関しては，スペースの都合もあり， 詳細を記さないが，センター全体の紹介が http://rsc.riken. jp にあるので，ご興味のある読者は参照されたい。また， SACLA に関する詳細は, http: // xfel.riken.jpにあり, SPring-8は, http://www.spring8.or.jp に詳細情報が載って いる.

\section{3.おわりに}

SPring-8 は2017年に，供用開始20周年を迎えた．20年間 沢山の利用者に使っていただき，多くの成果を産久出してき たのは，先端的なハードウェアがあったことは勿論であるが， SACLA を併設したことによる相乗効果も大きい.

しかしながら，この先も世界最先端放射光施設として日本 の放射光科学を牽引していくためには，このあたりでハード ウェアの更新とソフトウェアの作り替えが必要になってきた ように思われる. 理化学研究所ではそのための準備作業を進 めているが，実現に向けて皆様からのご要望をお聞かせ頂く とともに，ご支援を打願いしたい。

2017年10月11日受理[doi:10.2320/materia.57.27]

（連絡先 : ₹679-5148 佐用郡佐用町光都 1-1-1) 